\title{
Evolutionary Paths of Start-ups and Large Firms' Entrepreneurial Orientation: Combinations of Proactiveness and Competitive Aggressiveness
}

\author{
Yang YANG ${ }^{a,{ }^{*}}$ and Xiao-Feng JU ${ }^{b}$ \\ School of Management, Harbin Institute of Technology, China \\ akobeyang827@163.com, ,juxf@hit.edu.cn \\ "Corresponding author
}

\begin{abstract}
Keywords: Entrepreneurial orientation, Competitive moves, Competitive aggressiveness,
\end{abstract} Proactiveness.

\begin{abstract}
Based on combinations of proactiveness and competitive aggressiveness, this paper investigates start-ups and large firms' initial choices and general evolutionary path of entrepreneurial orientation dimensions. In initial choices, differences in resources endowment determines that start-ups may combine low competitive aggressiveness with high proactivenss, while large firms may prefer high competitive aggressiveness and low proactiveness. In general evolutionary path, the competitive characteristics and developing dilemma may lead to various paths.Specifically, the three-section evolutionary routine of start-ups are high proactiveness and low competitive aggressiveness, high proactiveness and competitive aggressiveness, low proactiveness and high competitive aggressiveness; but that of large firms are high competitive aggressiveness and low proactiveness, high competitive aggressiveness and proactiveness, low competitive aggressiveness and high proactiveness.
\end{abstract}

\section{Introduction}

In dynamic and fast changing environment, entrepreneurial orientation(EO) is of great importance to firms' survival and development[1,2]. EO is a strategy that fit for start-ups and large firms. Scholars have conceptualized EO as an uni-dimensional construct, based on factors such as innovativeness, risk taking, and autonomy $[3,4]$, and measured by a composite approach. It was assessed as an overarching strategy, regardless of unique influence of specific EO dimensions[5]. Research that adopt multidimensional conceptualization of EO is lacked[6]. In addition, prior research do not differentiate proactiveness from competitive aggressiveness and may even regard them as equivalent. Also, comparing with innovativeness and risk-taking, fewer research has been focused on proactiveness and competitive aggressiveness[7]. What's more, scholars agree that new venture and large firms have different competitive moves[8,9].They are keep silence in how competitive moves differences affect combinations of EO dimensions. At last, prior studies mainly concentrated on static perspective, that is the initial choice, and don't further investigate whole evolutionary path from dynamic perspective. In fact, despite of differences in initial choices, start-ups and large firms may adjust their competitive moves when facing different developing dilemma. The adjustments lead to different evolutionary paths. Therefore, this paper investigates start-ups and large firms' initial choices of combinations of proactiveness and competitive aggressiveness.Further, it demonstrates the general evolutionary paths of not only start-ups, but also large firms. The reminder of this paper is organized as follows. In the next section, we conduct theoretical analysis of EO. We then link competitive moves to various combination of proactiveness and competitive aggressiveness. The last section is conclusion and discussion. 


\section{The Conceptualization and Dimensions of EO}

\section{Conceptualization of EO: Overarching Strategic vs Muti-dimensional}

Comparing with conservative ones, firms with strong EO are more likely to support creative activities and experiments, tend to engage resource commitment to innovative projects that with high risk, also they may give innovative teams and their members more independence to determine how to conduct product innovation[6,7], may prefer explore new opportunities to merely exploit current ones, they may also pay attention to their rivals' moves[4].There are two perspectives to conceptualize EO, that is, composite and muti-dimensional. The composite approach regard EO as an overarching strategy which has been made up by three dimensions. They are innovativeness, risk-taking and proactiveness[3,4].However, from muti-dimensional perspective, scholar tend to investigate the effects of unique dimensions and EO is made up by five dimensions, innovatiness, risk-taking, proactiveness, competitive aggressiveness and autonomy [5,6,7].In fact, firms with strong EO may choose be more aggressively pursuing several factors, but less aggressively pursuing other factors[10].

\section{Dimensions of EO: Internal vs Competitive Move Perspective}

In multidimensional approach, prior literature pay more attention to innovativeness, risk-taking and fewer scholar focuses on proactiveness and competitive aggressiveness. Because previous literature not differentiate proactiveness from competitive aggressiveness. In composite perspective, these two dimensions are regarded as equivalent[4]. In fact, these EO dimensions actually represent two different modes by which firms view and act on the business environment.Proactiveness refers to the preemptive actions of a firm, firms with high proactiveness may prefer exploring potential new opportunities to merely exploiting current ones.However,competitive aggressiveness refers to a firm's responses to competitors' challenges. High aggressiveness means firms may attempt to outperform their competitors by respond nimbly to rivals' actions[7]. In addition, unlike innovativeness, risk-taking and autonomy which are from internal perspective, competitive aggressiveness and proactiveness are from external and competitive moves perspective. Competitive aggerssiveness is similar to responses of competitive moves, while proactiveness is similar to actions[8]. Various combination of proactiveness and competitive aggressiveness can be regard as different kinds of competitive moves.

\section{Competitive Moves and Combinations of EO Dimensions}

\section{Resource Endowment and Initial Choices}

For both start-ups and large firms, competitive moves are vital for them to gain competitive advantage[11]. The initial choices of EO are determined by firms' resource endowment. Start-ups should get rid of head-to-head confrontation with large firms in current and mainstream market, instead they should conduct guerrilla warfare[11]. They may take advantage of flexibility and search for low-end or emerging markets which large firms are reluctant to enter or unaware of as stronghold[9,12]. As for large firms, sufficient financial and managerial resources, valuable customers' loyalty, unique brand reputation and a series of routines and values ensure that they can handily exploit current opportunities and meet demands of high-end and mainstream markets. When facing their rivals' threats in current opportunities, large firms may devote more resources to invest in marketing and manufacturing capacity to fight against. Also, because of pressure of rapid growth, large firm prefer allocating their resources to the mainstream markets where the customers' demand is certain and the financial profit is high to low-end or emerging market which is characterized by uncertain customer demand or low financial profit[9].Therefore, start-ups' initial choices of combination of EO are high proactiveness and low competitive aggressiveness, while that of large firms are high competitive aggressiveness and low proactiveness. Start-ups seek low-end or emerging market to survive, large firms focuses on high-end and mainstream market to gain or expand competitive advantages. 


\section{Developing Dilemma and Evolutionary Path}

Developing Dilemma.Despite of different initial choice, two kinds of firms may also have different developing dilemma. They should adjust their combinations of EO to overcome these dilemma, therefore resulting in the general evolutionary paths. By entering the low-end market with low profit or emerging market with uncertain customer needs, start-ups may achieve scale development in certain extent. At this time, they need to engage different entrepreneurial group to enter mainstream and high-end market. By doing this, they may achieve fast growth,even overturn large firms. Start-ups intend to go from low-end to high-end market. They not only exploit current opportunities(which large firms are reluctant to enter or unaware of), but also explore potential new opportunities(which are dominated by large firms)[12,13]. For large firm, its development dilemma is how to use unique entrepreneurial groups to explore potential new opportunities and find new businesses for future growth .In order to get rid of silicon valley paradox and innovators' dilemma[12], large firms may make themselves work like start-ups and maintain innovative to realize business transformation. Various developing dilemma and different competitive characteristics lead to different general evolutionary paths between start-ups and large firms.

General evolutionary path of combinations of EO dimensions.Start-ups. First stage(initial choice), high proactiveness and low competitive aggressiveness. Low-end and emerging markets are not attractive to large firms, but start-ups can rely on these markets to survive and achieve scale development[12]. Second stage, high proactiveness and competitive aggressiveness. After large firms retreat from low-end or emerging markets, the rivalry among start-ups are aggravated. In order to maintain competitive advantage, start-ups on one hand should engage head-to-head confrontation with other start-ups in low-end or emerging markets, on the other hand, they should make use of cost structure advantage which is built in low-end and emerging markets to enter high-end and high-profit markets. Third stage, high competitive aggressiveness and low proactiveness. After start-ups gain their stronghold in high-end markets, they may prefer allocating resources to high-profit markets to addicting to cut-throat competition in low-profit markets. To compete with their peer large firm, start-ups should focus their advanced resource on core businesses. Therefore, they may retreat from low-end or emerging markets which can't provide them with fast growth and high profit. Large firms. First stage(initial choice), high competitive aggressiveness and low proactiveness. In this stage, large firm are reluctant to enter low-end or emerging markets, instead, they focus their advanced resource on mainstream customer needs and engage head-to-head confrontation with the competitors. Second stage, high competitive aggressiveness and proactiveness. In this stage, start-ups' entering would reduce the growth speed of high-end markets. Large firm should on one hand compete with other rivals to maintain their competitive advantage in mainstream markets, on the other hand, they should pay attention to search for new opportunities that can offer them with future growth. Although managers of large firms know that this way is correct, it is hardly an easy task. In fact, the value and unique routines which make contribution to their success may hinder large firms to cope with exploitation and exploration at the same time. Instead, when facing start-ups' threats, large firms may further retreat from parts of high-end markets and limit themselves in a smaller range in high-end markets which may provide them with higher profit[12]. Third stage, high proactiveness and low competitive aggressviness. In this stage, large firms try to release from overshooting current mainstream markets and homogeneous competition among peer large firms, they endeavor to search and build new rapidly growing markets at the expenses of current profits.By doing this, large firms may gain sustainable competitive advantage, rather than merely temporary advantage[13].As mentioned by prior literature, when firms are addicted to homogeneous competition for the same opportunities, they may attach undue importance to competitors, therefore neglecting product innovation and customers' needs. This may lead to firms' immature new products or products that can't meet customers' demands[14].

To sum up, the general evolutionary paths of start-ups' EO groups are as follows: initial choice is low competitive aggressiveness and high proactiveness, then transforms to high proactiveness and competitive aggressiveness, eventually high competitive aggressiveness and low proactiveness. 
This path demonstrates the process of start-ups' creation, scale development and rapid growth. The general evolutionary paths of large firms' EO group reveal the process of large firms' transformation. The path starts from high competitive aggressiveness and low proactiveness, then high proactiveness and competitive aggressiveness, eventually high proactiveness and low competitive aggressiveness. Table 1 describes the competitive characteristics of each section and depicts three sections of general evolutionary paths of start-ups and large firms' EO groups.

\section{Conclusions and Discussion}

This study focuses on the combination of two EO dimensions, competitive aggressiveness and proactiveness and demonstrates start-ups and large firms' initial choices of combinations of competitive aggressiveness and proactiveness and their whole general evolutionary paths.In initial choices, differences in resources endowment lead to various competitive moves, then resulting in different combinations of EO dimensions. Instead of competing with large firms in high-end markets, start-ups tend to search for low-end or emerging markets which are not attractive to large firms to make a living.So, it may combine high proactiveness with low competitive aggressiveness. For large firms, they may choose high competitive aggressiveness and low proactiveness to maintain competitive advantage in high-end mainstream markets and give up low-end markets or emerging markets that with uncertain customers' demands. In evolutionary paths, developing dilemma of each stage leads to different competitive moves, then resulting in different general evolution paths of two kinds of firms. Specifically, start-ups may along with a three-stage path. The path begins with high proactiveness and low competitive aggressveness, then high competitive aggressiveness and proactiveness, at last, low proactiveness and high competitive aggressiveness. Large firms also have a three-stage path. Their path begin with low proactiveness and high competitive aggressiveness, then high proactiveness and competitive aggressiveness, eventually low competitive aggressiveness and high proativeness. This paper has several theoretical implications. To begin with, it calls for scholars to investigate unique combinations of EO dimensions. They may identify the interaction effects of different EO dimensions to product innovation or firm performance. In addition, despite of statics perspective, scholars may pay attention to whole dynamic evolution paths of firms' EO.This study depicts a picture that can help us understand the whole developing process, rather than single section, of start-ups and large firms. We can learn that how start-ups and large firms may adjust their EO groups to overcome development dilemma and maintain competitive advantages. For start-ups, the dilemma is how to achieve scale development and fast growth, while for large firms, the dilemma is how to search for rapidly growing new markets to achieve transformation.

\section{References}

[1] Xie Hongwen, Cheng Cong.Does EO enhances firm performance?: a examination of Mete analysis. Studies in Sciences of Sciences,30(7)(2012) 1082-1091.

[2] Yin Miaomiao, Bi Xinhua,Wang Yaru.The relationship between new ventures' EO,opportunity orientation and firm performance: empirical analysis from Chinese context.Journal of Management Sciences in China,18(11)(2015) 47-57.

[3] Covin JG, Slevin D.,Strategic management of small firms in hostile and benign environments. Strategic Management Journal 10(1)(1989) 75-87.

[4] Miller D.,The correlates of entrepreneurship in three types of firms. Management Science 29(7)(1983): 770-791.

[5] Wales W.J., Patel P.C., Parida V. and Kreiser P.M., Nonlinear effects of EO on small firm performance: The moderating role of resource orchestration capabilities. Strategic Entrepreneurship Journal (7)(2013) 93-121. 
[6] Lumpkin GT, Dess GG. ,Clarifying the EO construct and linking it to performance. Academy of Management Review(1996) 135-172.

[7] Lumpkin GT, Dess GG.,Linking two dimensions of EO to firm performance: The moderating role of environment and industry life cycle. Journal of Business Venturing 16(5)(2001).

[8] Chen MJ, Hambrick DC., Speed, stealth, and selective attack: How small firms differ from large firms in competitive behavior. Academy of Management Journal 38(1995) 453-482.

[9] Katila R, Chen EL, Piezunka H., All the right moves: how entrepreneurial firms compete effectiviely. Strategic Entrepreneurship Journal 6(2012) 116-132.

[10]Lyon, DW, Lumpkin GT and Dess.GG., Enhancing EO research: Operating and measuring a key strategic decision making process. Journal of Management 26(5)(2000) 1055-1085.

[11]Chen MJ, Miller D.,Competitive attack, retaliation, and performance: an expectancy-valence framework. Strategic Management Journal 15(2)(1994) 85-102.

[12]Clayton M. Christensen. The innovators' dilemma when new technologies cause great firms to fail. Havard Business School Press,Boston,1997

[13]Clayton M. Christensen, Michael E. Raynor.The The innovators' solution creating and sustaining successful growth. Havard Business School Press,Boston,2003.

[14]Katila R, Chen EL. ,Effects of Search Timing on Innovation: The Value of Not Being in Sync with Rivals. Administrative Science Quarterly 53(4)(2008) 593-625. 
Table 1: The General Evolutionary Path of Start-ups and Large Firms' EO: Combinations of Proactiveness and Competitive Aggressiveness

\begin{tabular}{|c|c|c|c|c|c|c|}
\hline \multicolumn{7}{|c|}{ Different combinations of proactiveness and competitive aggressivness and their competitive traits } \\
\hline $\begin{array}{l}\text { Evolution } \\
\text { Path }\end{array}$ & \multicolumn{3}{|c|}{$\begin{array}{l}\text { Start-ups:search for a stronghold-scale } \\
\text { development-rapid growth }\end{array}$} & \multicolumn{3}{|c|}{$\begin{array}{l}\text { Large firms:overshooting high-end markets-search for } \\
\text { future fast growth markets }\end{array}$} \\
\hline Stages & $\begin{array}{c}\text { Initial choice: } \\
\text { high } \\
\text { proactivenss } \\
\text { low } \\
\text { competitive } \\
\text { aggressivenes }\end{array}$ & $\begin{array}{c}\text { Stage } 2 \text { :high } \\
\text { proactiveness } \\
\text { high competitive } \\
\text { aggressiveness }\end{array}$ & $\begin{array}{c}\text { Stage } 3 \text { :low } \\
\text { proactiveness } \\
\text { high competitive } \\
\text { aggressiveness }\end{array}$ & $\begin{array}{l}\text { Initial choice:low } \\
\text { proactiveness } \\
\text { high competitive } \\
\text { aggressivenes }\end{array}$ & $\begin{array}{c}\text { Stage 2: high } \\
\text { proactiveness } \\
\text { high } \\
\text { competitive } \\
\text { aggressiveness }\end{array}$ & $\begin{array}{c}\text { Stage } 3 \text { : high } \\
\text { proactiveness } \\
\text { low competitive } \\
\text { aggressiveness }\end{array}$ \\
\hline $\begin{array}{l}\text { Competitive } \\
\text { Traits }\end{array}$ & $\begin{array}{l}\text { (1)Be flexible } \\
\text { and get rid of } \\
\text { head-on } \\
\text { confrontation } \\
\text { with large } \\
\text { firms } \\
\text { (2) Search for } \\
\text { low-end or } \\
\text { emerging } \\
\text { markets as } \\
\text { stronghold }\end{array}$ & $\begin{array}{l}\text { (1)Compete with } \\
\text { other start-ups in } \\
\text { low-end or } \\
\text { emerging } \\
\text { markets (current } \\
\text { opportunities) } \\
\text { (2)Enter } \\
\text { high-end markets } \\
\text { to compete with } \\
\text { large firms } \\
\text { (attractive new } \\
\text { opportunities) }\end{array}$ & $\begin{array}{l}\text { (1)retreat from } \\
\text { low-end markets } \\
\text { (2)Focus advanced } \\
\text { resources and rely } \\
\text { on their dominant } \\
\text { cost structure to } \\
\text { compete with } \\
\text { large firms in } \\
\text { high-profit } \\
\text { markets } \\
\text { (3)re-position core } \\
\text { businesses } \\
\text { (4)Motivation to } \\
\text { explore new } \\
\text { markets weaken }\end{array}$ & $\begin{array}{l}\text { (1)Use resources } \\
\text { endowment to } \\
\text { expand } \\
\text { competitive } \\
\text { advantage in } \\
\text { high-end markets } \\
\text { (2)For fast growth } \\
\text { pressure, lack } \\
\text { motivation to } \\
\text { enter emerging } \\
\text { markets } \\
\text { (3)clap blinding } \\
\text { diversity trap, } \\
\text { re-position firms' } \\
\text { core businesses }\end{array}$ & $\begin{array}{l}\text { (1)Facing } \\
\text { attacks from } \\
\text { start-ups from } \\
\text { low-end, large } \\
\text { firms transfer } \\
\text { to a smaller } \\
\text { range of } \\
\text { high-end } \\
\text { markets } \\
\text { (2) Diversity. } \\
\text { endeavor to } \\
\text { enter emerging } \\
\text { markets or } \\
\text { unrelated } \\
\text { fields to build } \\
\text { future growth }\end{array}$ & $\begin{array}{c}\text { (1)Don't } \\
\text { overshooting } \\
\text { high-end markets } \\
\text { (2)Transform to a } \\
\text { flexible distributed } \\
\text { organization which } \\
\text { is made up by lots } \\
\text { of } \\
\text { micro-enterprises } \\
\text { to match } \\
\text { customers' needs in } \\
\text { large } \\
\text { scaled ,low-end or } \\
\text { emerging markets } \\
\text { acutely to build } \\
\text { new businesses for } \\
\text { future growth. }\end{array}$ \\
\hline
\end{tabular}

